УДК 349.42(98)

\title{
Food Security of Arctic Territories Legal Regulation
}

\author{
Andrey A. Kondrashev, Mariia E. Nikitenko, \\ Inna B. Trofimova, Svetlana A. Trofimova \\ and Larissa G. Gotsko* \\ Krasnoyarsk State Agrarian University \\ 90 Mira Av., Krasnoyarsk, 660017, Russia
}

Received 01.06.2016, received in revised form 25.07.2016, accepted 16.08.2016

The article researches the urgent under modern conditions issues of legal regulation of food security of the Arctic regions of Russia the regions of the Far North of the Krasnoyarsk Territory in particular. Special attention focuses on the active involvement of the population of the Arctic areas and the indigenous peoples of the Far North in the food self-sufficiency with the use of the nature management production of indigenous peoples.

Keywords: Arctic regions, food security, the traditional nature management territory, indigenous peoples.

The study was made possible thanks to the financial support from the Regional State Autonomous Institution "Krasnoyarsk Regional Fund of scientific and technical activities support" in the framework of the competition for social and humanitarian research, development and innovation aimed at improving the quality of life of the Krasnoyarsk Territory population. Protocol № 46, May 27, 2016.

DOI: 10.17516/1997-1370-2016-9-9-2184-2193.

Research area: law.

\section{Introduction}

The increasing role of the Arctic in terms of geopolitical interests (economic, political, military) of the Arctic powers (Russia, USA, Canada, Denmark, etc.) is associated with the new facilities for the Northern Sea Route use as a leading traffic artery, the extraction of hydrocarbons in the Arctic ocean sea shelf and others.

Arctic territories countries (Declaration on the Establishment..., 1996) are encountering security problems sharpening in various areas namely defense, environmental and food ones (www.securitymedia.ru/newsone1898.html).

Formation of the Arctic military force enables Russia to solve the problems of military security to some extent. Accommodation of the Ministry of Emergency Situations special units in the Arctic to prevent and eliminate technological accidents consequences will contribute partially to environmental safety.

The matters of the modern state of the food security system of the population of

(C) Siberian Federal University. All rights reserved

* Corresponding author E-mail address: iness.kastilia@mail.ru 
the northern, polar and Arctic regions have recently become the research issues of several groups of the Ural scientists. The report "Strategic priorities of the formation of the food security system of northern, polar and Arctic regions" ( Polbitsin, DrokinZhuravlev, 2012) gave the results of the food security system research in some areas of the Far North. The general conclusion is: the main priority of the food system formation is the development of a sociological form of food security system based on the supply of the major part of provisions from the European part of the country and Siberian regions.

The regions' facilities of self-sufficiency have remained significantly under researched. The more interesting paradigm of the Arctic zone assimilation and development has been reasoned by another group of researchers (A.I.Tatarkhin, E.A. Zakharchuk, V.G. Loginov). Its foundation has become a concept of the agro - innovative system of the region. Its goal is food security of the Arctic population by means of the new knowledge and technologies creation, dissemination and implementation. The mechanism of the gradual formation of the agro - innovative food security system is suggested (www.securitymedia.ru/ newsone1898.html).

The authors specify the conditions affecting the organizational mechanism of food security:

- The amount of population, including indigenous people;

- The current level of consumption and recommended consumption rates;

- The ratio between the resident and external population;

- Extreme climatic conditions;

- Poor infrastructure;

- Agricultural production volume in the area;

- Seasonal restriction of the production supply.
The North indigenous peoples' possibilities to take part in the food supply of the Arctic region turned out to be beyond the bounds of the list.

We consider themore purposefulinvolvement of the indigenous peoples in food security issues solution to be necessary.

Dolgan-Nenets, Evenk municipal region and Turukhansk region belong to the Arctic territories of the Far North of the Krasnoyarsk region. 67 thousand people live on these territories (which equal four territories of France) and about 15 thousand out of this number should be referred to Indigenous Peoples.

A significant part of indigenous peoples are engaged in traditional life activity (http://www. raipon.net). Its specific features play an important role in their identity.

Factors affecting the formation and development of the peoples of the Far North (paucity, harsh climatic living conditions, remoteness and isolation from the main territory of the country, which even today is commonly known as "the mainland"), used to provide a dual impact on this process.

On the one hand, these factors hindered the development process, and on the other hand they have contributed to the preservation of the specific features of a peculiar "northern culture," which made it possible to co-exist in a unique "symbiosis" with the nature.

The main source for indigenous peoples' existence was hunting, fisheries and reindeer breeding. Natural economic setup was preserved. Low technical level of the instruments of production associated with low productivity, poor development of social division of labor and exchange, as well as seasonal hunting and fishing led to the fact that none of the branches of the economy could have provided the material needs on their own. Every household combined several kinds of activities, which contributed to the concentration of interests within a tribal or clan 
group to more extent. Handmade production, that is processing of fishing, hunting, reindeer breeding products as well as making labour and household tools, which, however, despite their apparent primitiveness, used to be original and functional i.e. met their intended purpose was widely developed.

Public consciousness of northern indigenous peoples was formed under severe conditions of everyday life and was reflected in the creative abilities of people who had learned to extract necessary material goods from the severe nature to brighten up their monotonous life by the means available (bone carving, embroidery of traditional clothing, etc.) (The development strategy..., 2013).

Amateur, folk and fine arts, giving the impression of the social economic situation of the tribes were developed under the patriarchal tribal system conditions.

Spontaneous materialism was reproduced in the public consciousness of the Far North peoples. In the process of procuring their living, the man realized that objects of the world exist outside and regardless of the peoples' consciousness and will. It made him pattern their behavior correctly in order to adapt and survive under the severe climatic conditions of the North. The northern people practice helped acquire learning in the field of biology, geography and meteorology.

The relationships between the members of such a community in their daily inner life were regulated by customary law that is the complex of established norms which, according to $\mathrm{N}$. Rulan can do without the state (Resolution of the Administration..., 2003).

Standards having the shape of conventions, traditions, rituals, customs, etc. formed the orthodox bases of a tribe regulated productive, property, matrimonial, criminal legal relations of people.

At the same time, the circumstances of the "outside world" could not help affecting the indigenous peoples. The existing more or less close contacts of the North indigenous peoples' representatives and the dominating Russian population, the northern tribes, and the Russian state objectively contributed to the spread of the influence of the Russian cultural factors on indigenous peoples' life. The latter happened to be in a situation of conflicting interaction with the Russians and their State, which formally accentuated its policy of non-interference in the internal affairs of the nomadic peoples of the north, who by the way, were symptomatically called "non - Russians".

Under the reign of Alexander I an attempt to develop a charter, which would regulate the relations of the authorities and the indigenous population was made. The charter draft set forth the conditions of the relationship in the sphere of land use, trade, taxes, self-government and defense. These conditions limited the state invasion of the internal life of indigenous peoples at most. Russian people were even forbidden to settle on the land transferred into the possession of the aborigines.

Events of 1917 burst into the life of all Russian people changed radically a lot in the way of their life, not leaving aside the indigenous peoples of the Far North either. The effects of the new realities of the established Soviet authorities on the indigenous northerners' existence also had a controversial character.

Soviet power, unlike the tsar's one, did not plan to keep from the attention to the indigenous peoples' life by any means. However, the quality of the Soviet state impact on the lifestyles of indigenous peoples and their social consciousness is assessed in terms of the attitude to the actual events of 1917 and to the forthcoming period.

If literature and archival sources of the $60 \mathrm{~s}, 70$ s fail to contain any critical statements concerning the policy pursued by the Soviet government in regard to the peoples of the Far 
North, then the work of a later period abounds in such statements. So, some modern authors note that the tsar's authority indifference to the northerners proved to be more humane than the policy of the Soviet intervention in the ways of reforms, attempts to include indigenous peoples' into the socialist way of life, bypassing millenniums (Trofimova, 2007).

The impact of such things as technology uptake, interference in the social life of indigenous peoples, and so on can be assessed in two ways: in fact, in addition to the labor process advancement, literacy growth of the population, involvement in the world culture, it led to an imbalance in the relationship with nature, tradition breaking, the spread of diseases and so forth.

The following factors are usually pointed out among the negative ones: the destruction of the traditional collectivist way of life, forcible transfer to sedentary lifestyle, dramatic decrease and in some places complete extermination of reindeer, industrial emissions into atmosphere, leading to acid rains and destruction of reindeer pastures as well as damage to topsoil by powerful technology, replacement of traditional food by cereals and pasta in dietary intake etc., parenting children starting with toddlers out of touch with their parents and the tundra and as the result they turned into people able to live neither in a traditional way of life nor in industrial environments, alcohol abuse, increase in the number of suicides, the extinction of the indigenous population.

Thus, over the Soviet period the indigenous peoples of the Far North development was characterized by contradictory processes: on the one hand - strengthening links between the Russian and indigenous peoples, on the other the spread of diseases, alcoholism; on the one hand - the improved quality of life, nutrition; on the other - disturbance of harmonious relationship with nature, on the one hand - the formation of a new type of society, the "germs" of a civic society, on the other- the loss of some original traditions.

In modern epoch difficulties and problems the indigenous peoples encounter have not diminished. The market economy, the Russian version of which is often characterized by figurative definition of "wild" has revealed quite a few surprises not only to the indigenous peoples of the Far North, but to the dominant population of the Russian state as well. Economic principles of the society organization have changed; public consciousness has experienced a shock. Geopolitical conditions of the indigenous peoples of the Far North existence who are still predominantly isolated from "the big land", "the continent", made changes especially painful. To analyze the problems of the indigenous peoples of the Far North over the post Soviet stage we conditionally divide them into two blocks: economic and sociocultural (Resolution of the Administration..., 2003).

The most important part of the traditional way of life of the peoples of the Far North is a reindeer breeding. It should be noted that the reindeer breeding is not only the economic basis of the community of indigenous peoples of the Far North, but a cultural, social, and religious one as well. It used to be and is the core of the original life of the Northern community as a whole. Therefore, the state of reindeer breeding husbandry affects not only the economic wellbeing of northerners, but their social organization and the public consciousness either. The lack of an established system of reindeer products marketing (meat, fells, antlers) led to a sharp decrease in the number of domestic reindeer, and a big number of tribal communities' refusal of dealing with reindeer herding.

As to fishery the reforms resulted in the destruction of the integral and sufficiently 
effective system of administrative management of the fishery, fish stock reproduction and processing.

As with hunting, an increase in fish capture and fish transport costs led to the fact that the fishery was concentrated on the most valuable species (sturgeon, and semi - whitefish: Siberian white salmon, whitefish, broad whitefish, peled and others).

The catch of less valuable fish species reduced significantly (burbot, fine-mesh fish), which used to account for 30 to $50 \%$ of the catch in some northern areas. All this leads to a decrease in resources of fish jeopardizing them to extinction.

Asaresult of commercial farms disaggregation in a number of organizations of different ownership forms, which receive official permission to catch valuable limited fish species has increased in several times. It does not only complicate the work of fishery inspection, but does not contribute to environmental well-being either.

Another trade within the category of traditional northern peoples' ones is fur trade. This branch failed to escape the crisis occurrences as well. Furs procurement reduced significantly due to a decrease in prices of the skins of wild animals in particular and an increase in the cost of ammunition and other hunting equipment. Skins of a white fox and a squirrel have almost devalued; sable prey revenues have decreased which resulted in the majority of the wildlife plots abandoned in the tundra. For lack of forage, raw materials and means of wages payment the majority of the northern fur farms were closed down everywhere, as well as workshops for sewing fur products, and souvenirs production.

Thus, the destruction of the northern Aboriginal economic life foundations - reindeer breeding, maritime, fishing and fur trade lead to the whole range of consequences: economic, environmental, social, cultural crisis, to a breakdown of the entire traditional lifestyle of the indigenous population of the Far North.

Experts dealing with indigenous peoples (Trofimova, 2007) note that the authorities throughout all periods under review (prerevolutionary, Soviet and modern ones) had "absolutely wrong impressions" about the indigenous peoples' traditional way and mode of life as the solutions made by them (the authorities) evidence. In 2016 in particular the RF Ministry of Agriculture prohibited fishing smelt without taking into account the needs of indigenous peoples of the Far East (Men'shikov, 2014), in 2014 the similar prohibition was in effect concerning whitefish catch in the Tomsk Region, Khanty-Mansiysk District - Yugra, in the Yamalo-Nenets Autonomous Area (Order of the Ministry..., 2013).

As a result we are facing the problem of the preservation of the indigenous peoples' fate and life of the valuable natural areas not mutilated by the industrial civilization left on Earth. Obviously, its solution lies in the area of legal regulation of production and resources processing rules area.

The developed countries have already reduced the production and processing of resources in their territories and seek to transfer it into the territory of developing countries. Russia has turned out to be in one row with the latter.

Efficient resources use is the basis of any economic strategy. The matter of the balance between their reproduction and consumption within the traditional nature management remains a major challenge for sustainable economic development of indigenous peoples of the Far North. Its solution requires the search for a compromise among three largely conflicting goals: the fullest possible preservation of cultural traditions, the maximum economic benefits and the greatest preservation of natural ecosystems.

The Russian government has approved of the plan of the state national policy strategy 
measures until 2025. It emphasizes its goal: "the preservation and development of ethnic and cultural diversity of the peoples of Russia", and enshrines the principle of guaranteeing the rights of indigenous peoples, including support of their economic, social and cultural development, protection of original habitation and traditional way of life.

Creation of the conditions for the indigenous peoples' participation in a decision-making process affecting their rights and interests is determined to be the major goal.

The program suggests "the improvement of the local self-government organization with regard for the possibility of using traditional forms of self-organization of the peoples of Russia." Tribal communities are used to be such a form in respect to the indigenous peoples of the North.

One of the goals to ensure the equality of the citizens according to the Strategy of the state national policy up to 2015 is "the creation of the conditions for the citizens to freely determine their ethnic origin" (The strategy of the state national..., 2013).

Assistance in promotion of folk arts and crafts in order to increase population employment, including the areas traditionally inhabited by indigenous peoples with their traditional economic activities is referred to the socio-economic conditions of the effective implementation of the state national policy.

Regulation of the legal status of indigenous peoples of the Far North of Krasnoyarsk Territory of their traditional economic activity is based on the Federal Law on 7.05.2001 №49 FZ (ed. 31.12.2014) “On Traditional Nature Territories Use of Indigenous Peoples of the North, Siberia and the Far East of the Russian Federation"[17], The Law of the Krasnoyarsk Territory on 25.11.2010 №11-5343 (ed. on 12.19.2013) “On the protection of the primordial habitation and traditional way of life of the indigenous Peoples of Krasnoyarsk Territory" (The Law of the Krasnoyarsk Territory..., 2010).

These legal acts give the definitions of such concepts as a reindeer herder, a hunter, a fisherman, traditional habitation and its protection, types of nomadic dwelling.

These definitions themselves cause tribal communities of the North indigenous peoples' representatives' numerous queries:

- ambiguity of criteria for classifying persons engaged in fishing, hunting, reindeer breeding to a particular profession, as the professions in question are wanting in the Classifier;

-impossibility to correlate types of nomadic habitation with the types of premises specified in the Russian Federation Code of Housing;

- the order of formation of the territory of traditional nature management and their attachment to certain communities has not been determined yet.

Furthermore, the legal acts in question do not define the legal basis of the tribal communities' interrelations with industrial companies engaged in the subsoil mine workings in the territories of the traditional use of indigenous people, which leads to the destruction of the habitation of indigenous peoples. Indigenous peoples are deprived of the opportunities to claim compensation for their land use, which results in the traditional trade degradation and the population of the Arctic territories impoverishment.

All this complicates the problems solution in terms of the population of the Arctic areas and the indigenous population of the Far North involvement in the food and economic security in the period of the Arctic development enhancement.

Food security in the Arctic should be based with the view of the possibilities of establishing agro - innovative systems of the region, as a whole, and singularity of separate areas and their opportunities in private self- sufficiency. 
To achieve these goals it is necessary:

- to make a consumer needs record and facilities analysis of each entity of the Russian Federation and municipality relating to the areas of the Arctic and the Far North;

- to create a single information system to forecast the Arctic areas of the Russian Federation population' needs in food participation;

- to evaluate the indigenous peoples' of the territories participation possibilities in food security issues solution;

- to consider the possibility to subsidize at the expense of regional and municipal budgets, and provide various grants to companies formed by the indigenous communities, and engaged in traditional activities;

- to develop and pass the regulations at the Federal level in order the budget funds of the territory compensate those social benefits that enterprises engaged in traditional activities pay their employees in connection with the work under the Far North conditions (regional factor, northern allowance), otherwise these enterprises' output is a priori unprofitable (Kharyuchi,2005);

- to create, including the participation of the subjects' authorities consumers' cooperation system in purpose of purchasing trade products and establishing primary processing of reindeer herding and fishery products with the use of the domestic equipment;

- to form the entrepreneur sector aimed at the production in the territories (to use micro-loans system options, positively proven in the Republic of Sakha (Yakutia, the Russian Federation));

- to analyze the local authorities' possibilities in food self-sufficiency;

- to resolve the fundamental issue of enshrining and using the indigenous peoples' traditional lifestyles territories;

- to elaborate the method of calculating damage caused to the territories of traditional nature management as a result of industrial development of resources, and the ways to compensate the indigenous peoples of the North for the harm done;

- to strengthen the activities of all state and local authorities to combat corruption, especially when dealing with the use of natural resources in the Arctic, northern food delivery arrangement, and others.

- to ensure the priority of indigenous peoples' of the Far North rights in the course of elaboration and implementation of any programs of the northern and Arctic regions' development.

A complex approach to food security matters solution implies the involvement of the population and the indigenous peoples of the Far North in the process, which would require an additional legal provision, as the current regulatory legal basis does not fully meet the requirements of the time.

Starting from the Decree of the President of the Russian Federation of 22.04.1992 №397 “On urgent measures to protect the habitation and economic activities of the indigenous peoples of the North" (Presidential Decree of 22.04.1992...) , 16 Federal laws, about 20 laws of the RF subjects, 3 Decrees of the RF President, 6 resolutions and 2 orders of the Russian Federation Government have been passed. We consider to be the most crucial ones

(Declaration on the Rights..., 2007; Declaration on the Establishment..., 2013; The Law of the Krasnoyarsk Territory..., 2010; Polbitsin, 2012; Order of the Ministry..., 2013; Rulan, 1999, Tatarkhin, 2015; Trofimova, 2007; Presidential Decree of 22.04.1992...).

On the whole, we can emphasize the positive experience of legal regulation both at the Federal level and at the level of the RF subjects, especially in the Republic of Sakha (Yakutia), the Yamalo-Nenets and Khanty-Mansi Autonomous Districts.

The Krasnoyarsk Territory laws "On Protection of original habitation and traditional 
way of life of indigenous peoples of Krasnoyarsk Territory" and "On state support of reindeer breeding" are seriously inferior to them concerning the elaboration of certain provisions, causing criticism of tribal communities of indigenous peoples of the north representatives. The authors of the scientific-practical commentary to these laws also point out the shortcomings and contradictory nature of the laws in question (Grinberg, 2015).

Article 1 of the Federal Law of 30.04.1999 №82-FZ "On the guarantees of indigenous peoples' of the Russian Federation rights" enshrines the right to gratuitous use of land of different categories in order to lead their traditional way of life in the areas of traditional habitation and traditional economic activities of indigenous peoples (Federal Law of 30.04.1999....).

In real life, the Land Code of the Russian Federation instead of gratuitous use lays down the rent for land use and the terms of use, which are much shorter than the maximum period of land lease (49 years).

The legal regulation of the traditional nature management territories (TNMT) of indigenous peoples is implemented at the federal level and the level of the Russian Federation entities. Article 10 of the Law of Krasnoyarsk Territory "On Protection of original habitation and traditional way of life of indigenous peoples of Krasnoyarsk Territory (The Law of the Krasnoyarsk Territory..., 2010) indicates that the legal regime of the TNMT is established by the provision. The provision itself is still in the process of elaboration. There are several examples of TNMT formation in the Russian Federation. A similar one - traditional nature management territory "Popigai" is formed in our region in 2003 (Resolution of the Administration..., 2004).

The lack of the provision hinders the process of formation consolidation, and development of indigenous peoples' TNMP in Krasnoyarsk Territory, as well as prevents their involvement in the Arctic territories food security problems solution.

Successful implementation of the state policy in the Arctic and food security problems solution are possible only with the active participation of the population of the Arctic territories and the involvement of the indigenous peoples of the Far North in this process, as well as under the proper legal support of this participation.

\section{References}

Assotsiatciia korennikh malochislennykh narodov Severa, Sibiri i Dal'nego Vostoka Rossiiskoi Federatsii. [Association of Indigenous Peoples of the North, Siberia and Far East of the Russian Federation], Available at: http://www.raipon.net. (accessed 5 October 2016), in Russian.

Deklaratiia prav korennykh narodov. Priniata General'noi Assambleei OON 13.09.2007 [Declaration on the Rights of Indigenous Peoples. Adopted by the UN General Assembly. 13.09.2007]. (SPS Garant), in Russian.

Deklaratiia ob uchrezhdenii Arkticheskogo Soveta (1996)]. [Declaration on the Establishment of the Arctic Council 1996.] Arctic region: problems of international cooperation. V 3. P.175-177. M. Aspect - the press. 2013. Moscow, 2013, pp. 175-177, in Russian.

Zakon Krasnoiarskogo kraia "O zachite iskonnoii sredi obitaniia I traditsionnogo obraza zhizni korennykh malochislennykh narodov Krasnoiarskogo kraia" Nash Krasnoiarskii krai [The Law of the Krasnoyarsk Territory on 25.11.2010. №11-5343 (ed. on 12.19.2013) «On Protection of original habitation and traditional way of life of indigenous peoples of Krasnoyarsk Territory»]. Our Krasnoyarsk krai. 7 December, 2010. № 89, in Russian. 
Kompleksnaya bezopasnost'Arkticheskih territorii.[Complex Safety of the Arctic territories. Available at: www.securitymedia.ru/newsone1898.html, in Russian.

Men'shikov, A. Minsel'hozzapretilvylovmuksuna. Rossijskaya Gazeta [The Ministry of Agriculture has banned fishing whitefish]. Russian Newspaper, 2014, Available at: https://rg.ru/2014/06/30/regurfo/muksun-anons.html, in Russian.

Grinberg, S.N. and others. Nauchno-practicheskii kommentarii k Zakonu Krasnoiarskogo kraia "O zachite iskonnoii sredi obitaniia I traditsionnogo obraza zhizni korennykh malochislennykh narodov Krasnoiarskogo kraia" i k Zakonu Krasnoiarskogo kraia "O gosudarstvennoi podderzhke severnogo olenevodstva v Krasnoiarskom krae". [Scientific-practical commentary to the Law of the Krasnoyarsk Territory "On Protection of original habitation and traditional way of life of indigenous peoples of Krasnoyarsk Territory" and to the Law of the Krasnoyarsk Territory "On state support of the Northern reindeer breeding in the Krasnoyarsk Territory"].Krasnoyarsk, 2015, P. 390, in Russian.

Polbitsin, S.N., Drokin, V.V., Zhuravlev, A.S. Strategicheskie prioriteti formirovaniia sistemi prodovol'stvennogo obespecheniia severnikh, polyarnikh $i$ arkticheskikh territorii. Upravlenie ehkonomicheskimi sistemami: ehlektronnyj nauchnij zhurnal. [Strategic priorities of the formation of the northern food supply system, polar and Arctic territories]. (Management of economic systems: electronic scientific journal. 2012. №11). Available at: http://uecs.ru/uecs47-472012/item/1636-201211-07-06-21-04, in Russian.

Postanovlenie adminstratsii Taimyrskogo (Dolgano-Nenetskogo) avtonomnogo okruga ot 23.12.2004 g. №495 “O sozdanii territorii traditsionnogo prirodnogo pol’zovaniia "Popigai" [Resolution of the Administration of the Taimyr (Dolgan-Nenets) Autonomous District on 23 December 2003. №495 «On the formation of the traditional nature management territory "Popigai”], in Russian.

Prikaz Minsel'khoza Rossii ot 21.10.2013 N 385 (red. ot 19.04.2016) «Ob utverzhdenii pravil ribolovstva dlia Dal'nevostochnogo ribokhoziaistvennogo basseina». Zaregistrirovano v Miniuste Rossii. SPS «Konsul'tant - Plius» [Order of the Ministry of Agriculture of Russia on 21.10.2013 N 385 (as amended on 04.19.2016. "On approval of rules for fishing for the Far East fishery basin". Registered in the Ministry of Justice of Russia on 23.01.2014 N 31100]. (SPS Consultant), in Russian.

Rulan, N., Iuridicheskaia antropologiia [Legal Anthropology]. Moscow, Norma, 1999, P. 310, in Russian.

Strategiia razvitiia Arkticheskoi zony Rossiiskoi Federatsii $i$ obespecheniia natsional'noi bezopasnosti na period do 2010 goda (2013) [The development strategy of the Russian Arctic and national security for the period up to 2020 (2013). Arctic region: problems of international cooperation. V. 3. p.348, Moscow, Aspect - the press. 2013, in Russian.

Strategiia gosudarstvennoi natsional'noi politiki do 2015 goda. [The strategy of the state national policy up to 2025] Arctic region: problems of international cooperation. V. 3. p. 361, Moscow, Aspect - the press. 2013, in Russian.

Tatarkhin, A.I., Zakharchuk, E.A., Loginov, V.G. Sovremennaia paradigma osvoeniia i razvitiia Arkyicheskoi zony Rossiiskoi Federatii [The modern paradigm of the exploitation and development of the Arctic zone of the Russian Federation]. Arctic ecology and economy, 2015 №2, in Russian.

Trofimova, S.A. Mnogovariantnost' razvitiia grazhdanskogo obshchestva i integratsiia v nego korennikh narodov Krainego Severa (social'no-filosofskii analiz). [Multi-variant development of the 
civic society and integrating of the indigenous peoples of the Far North into it (socio-philosophical analysis)]. Krasnoyarsk State Agrarian University, Krasnoyarsk, 2007, p. 62-63, in Russian.

Ukaz Prezidenta Rossiiskoi Federatsii ot 22.04.1992g. № 397 «O neotlozhnykh merakh i zashchite mest prozhivaniia $i$ hozyaistvennoi deiaatel'nosti malochislennykh narodov severa» [Presidential Decree of 22.04.1992. № 397 “On urgent measures and the protection of habitation and economic activities of Indigenous Peoples of the North]. Bulletin of Congress of People's Deputies of the Russian Federation. 1992.№18. art.1009, in Russian.

Federal'nyi Zakon ot 07.05.2001g. № 49-FZ (v red. ot 31.12.2014) «O territoriyakh traditsionnogo prirodopol'zovaniia korennykh malochislennykh narodov Severa, Sibiri i Dal'nego Vostoka Rossiiskoi Federatsii [Federal Law of 07.05.2001, № 49-FZ (as amended on 31.12.2014) “On territories of traditional nature of Indigenous Peoples of the North, Siberia and Far East of the Russian Federation], (SPS Consultant), in Russian.

Federal'nyi Zakon ot 30.04.1999g. №82-FZ «O garantiiakh prav korennykh malochislennykh narodov Rossiiskoi Federatsii. [Federal Law of 30.04.1999, №82-FZ “On Guarantees of the Rights of Indigenous Peoples of the Russian Federation. (SPS Consultant), in Russian.

Kharyuchi, N.N., Zharomskikh, D.G. Pravovie osnovi organizatsii mestnogo samoupravleniia v mestakh prozhivaniia korennikh malochislennikh narodov Severa. [The legal basis of the organization of local selfgovernment in areas inhabited by indigenous peoples of the North]. Tiumen', 2005. P. 185, in Russian.

\title{
Правовое регулирование
}

\section{обеспечения продовольственной безопасности арктических территорий}

\author{
А.А. Кондрашев, М.Е. Никитенко, \\ И.Б. Трофимова, С.А. Трофимова, Л.Г. Гоцко \\ Красноярский государственный аграрный университет \\ Россия, 660017, Красноярск, пр. Мира, 90
}

\begin{abstract}
Данное исследование поднимает вопросы современного правового регулирования в обеспечении продовольственной безопасности арктических регионов России, а именно районов Крайнего Севера Красноярского края. Пристального внимания заслуживает активное вовлечение населения арктических территорий и коренных малочисленных народов Крайнего Севера в самообеспечение продовольствием и использование продукиии традиионной жизнедеятельности коренных малочисленных народов.
\end{abstract}

Ключевые слова: арктические территории, территории традиционного природопользования, продовольственная безопасность, коренные малочисленные народы.

Проведение данного исследования стало возможным благодаря финансовой поддержке краевого государственного автономного учреждения «Красноярский краевой фонд поддержки научно-технической деятельности» в рамках конкурса соииальных и гуманитарных исследований, разработок и инновачий, направленных на повышение качества жизни населения Красноярского края. Протокол № 46, 27 мая, 2016 г.

Научная специиальность: 12.00.00 - юридические науки. 